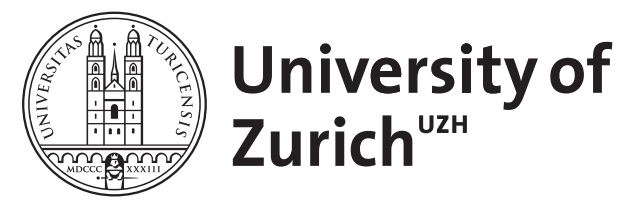

\title{
World Englishes and their dialect roots
}

\author{
Schreier, Daniel
}

\begin{abstract}
This chapter investigates the persistence and development of so-called dialect roots, that is, features of local forms of British English that are transplanted to overseas territories. It discusses dialect input and the survival of features, independent developments within overseas communities, including realignments of features in the dialect inputs, as well as contact phenomena when English speakers interact with those of other dialects and languages. The diagnostic value of these roots is exemplified with selected cases from around the world (Newfoundland English, Liberian English, Caribbean Englishes), which are assessed with reference to the archaic/dynamic character of individual features in new-dialect formation and language-contact scenarios.
\end{abstract}

DOI: https://doi.org/10.1017/9781108349406.017

Posted at the Zurich Open Repository and Archive, University of Zurich

ZORA URL: https://doi.org/10.5167/uzh-198161

Book Section

Published Version

The following work is licensed under a Publisher License.

Originally published at:

Schreier, Daniel (2020). World Englishes and their dialect roots. In: Schreier, Daniel; Hundt, Marianne; Schneider, Edgar W. The Cambridge Handbook of World Englishes. Cambridge: Cambridge University Press, 384-407.

DOI: https://doi.org/10.1017/9781108349406.017 


\section{7}

\section{World Englishes and Their Dialect Roots}

Daniel Schreier

World Englishes developed out of English dialects spoken throughout the British Isles. These were transported all over the globe by speakers from different regions, social classes, and educational backgrounds, who migrated with distinct trajectories, for various periods of time and in distinct chronological phases (Hickey, Chapter 2, this volume; Britain, Chapter 7, this volume). The dialects they spoke formed a foundation for the offspring varieties; some features either remained in more or less robust form or underwent farreaching structural and systemic change under local linguistic-ecological contact conditions. In this chapter, I will trace the dialect roots of New Englishes, that is, features that can clearly be retraced to regional dialects of the British Isles - what Hickey (2004: 1) has called "dialect input and the survival of features from a mainland source or sources." These "roots of English" (Tagliamonte 2012: 1) manifest themselves in regionally specific new-dialect formation processes (i.e. the emergence of World Englishes around the world) but also in the regional persistence of what Chambers (2009: 258) calls "vernacular roots." They are central for any reconstruction of the evolutionary formation of World Englishes in that they allow for an assessment of input strength and the impact of contact-induced mechanisms. I will discuss the importance of dialect roots for the formation of World Englishes (in terms of direct [conservative] legacies as well as contact-dynamic [e.g. camouflaged] forms), look into the diagnostic value of roots (suggesting a taxonomy of features) in what I would like to call first- and second-window transplantation scenarios, and, finally, present some reasons to account for why some dialect features take root whereas others disappear.

\subsection{Introduction: Picking the Roots}

This chapter deals with the legacy of British English in offspring varieties around the world, with a focus on the historical evolution and 
sociolinguistic implications of localized Englishes and their spread (Crystal 2003; Schneider 2011; Kachru, Kachru, and Nelson 2006). It looks into the emergence of new varieties indexed to certain social strata and speech communities (Schneider 2007, Mesthrie and Bhatt 2008), including ideology, identity construction, and globalization issues (Blommaert 2010). The question is to what extent these legacies of British varieties (Hickey 2004), in the form of dialect roots, come to be embedded into new language ecologies and how they develop on transplantation and subsequent adoption by speakers around the world (Lim and Ansaldo 2015).

One important misconception probably needs to be done away with right away. The input strength of dialect roots alone is not responsible for why World Englishes form the way they do. Contact-induced processes and interaction between systems may change the evolution of local varieties in addition to ongoing internal change, attesting to their dynamic and innovative character. Yet feature retention, as a consequence of dialect contact, is only one possible outcome of dialect transplantation, and Hickey (2004: 1-2) singles out a conglomerate of five factors that shape the sociolinguistic outcome of World Englishes:

" 1 . Dialect input and the survival of features from a mainland source or sources.

2. Independent developments within the overseas communities, including realignments of features in the dialect input.

3. Contact phenomena where English speakers co-existed with those of other languages.

4. An indirect influence through the educational system in those countries in which English arose without significant numbers of nativespeaker settlers.

5. Creolisation in those situations where there was no linguistic continuity and where virtually the only input was a pidgin, based on English, from the preceding generation."

This chapter primarily deals with complex 1 ("Input and survival"), whereas other factors (interaction, mixing, substratal effects, and the like) are kept to a minimum here (see Lim, Chapter 4; Hickey, Chapter 2; Fox, Chapter 20; D’Arcy, Chapter 19, all this volume). I will discuss features that have been transported outside the British Isles and that thus represent a legacy of the roots of (British) dialectal Englishes on a global scale (Tagliamonte 2012; see Britain, Chapter 7, this volume). In doing so, I partly follow Tagliamonte's (2012: 3) approach by focusing on "the historically embedded explanation that comes from tracing their roots back to their origins in the British Isles ... the study of British dialects is critical to disentangling the history and development of varieties of English everywhere in the world.” Though this may be rather general, I will approach roots as dialectal features that are permanently adopted in the emerging World Englishes (see taxonomy in Section 17.2). 
The first question in this context is what features are most likely to be transported and to which original dialects these are attributed. As Hickey (2004: 1) claims, it is "probably true to say that mainly regional forms of English were taken to the colonies which England founded in the core 200year period between the early seventeenth and the early nineteenth centuries." Regional forms were certainly important, yet not the only strand of language use in former British society. The majority of speakers who left the British Isles and migrated to overseas territories came from lower social ranks (lower middle and working classes); they brought their regional varieties to the new settings, so these featured as primary input varieties. This stock of low-strata social and regional varieties (which arguably reinforced each other, as many inhabitants of regional areas were from the working classes and had little or no education) combined to found a solid basis of the newly emerging local varieties (as shown in selected case studies in this chapter). One may even go as far as to say that the foundations of these Englishes were firmly entrenched in nonstandard varieties (see Schreier 2008 on "nonstandardization" and its consequences), even though this assessment is probably too general. The focus on nonstandard heritage has been advocated by Watts and Trudgill (2002: 27), who go as far as to claim that

Non-standard dialects have histories too, and these histories are sometimes especially helpful because, as a result of the absence of standardisation, many of the forces of linguistic change are played out in these varieties in a much more unfettered and revealing way than in a standard dialect.

This has triggered documentation of and research on so-called lesserknown varieties of English (Schreier et al. 2010; Williams et al. 2015), that is, mostly peripheral varieties that now have an important place in studies on dialect transplantation and produced fresh insights into the export and survival of dialect roots. Generally speaking, two questions are particularly important here, namely (1) identification and localizability of roots and (2) survival vs. loss on the new-dialect contact scenario. I will address these in Section 17.3.

One important question is how "roots" should be approached in the first place. There are various ways to describe and classify the dialectal contributions of World Englishes; the concentration of the overall distribution of features has some currency here. Such a classificatory attempt would include what Chambers (2004: 19) called "vernacular roots," a set of dialect features considered as universals that comprise

a small number of phonological and grammatical processes [that] recur in vernaculars wherever they are spoken ... not only in working class and rural vernaculars, but also in ... pidgins, creoles and interlanguage varieties.

(Chambers 2004: 128, quoted in Szmrecsanyi and Kortmann 2009: 37) 
Though the concept has given rise to criticism and engaged debates in the field (see the contributions to Filppula, Klemola, and Paulasto 2009), Chambers originally regarded these universals as "primitive features of vernacular dialects" (2003: 243), emphasizing that they were unlearned and innate: consonant cluster reduction, (-ing), past be leveling to was, multiple negation, and leveling of irregular verb forms.

Trudgill (2004), on the other hand, criticized the notion of vernacular universals when arguing that there was no such a thing as a major divide between standard and nonstandard (or vernacular) varieties of English (as Chambers suggested). Rather, he argued in favor of a "true typological split" (2004: 315) between high- and low-contact world Englishes; high contact led to simplification, which he believed to be the main distinguishing factor between the two ends of the divide (Trudgill 2009: 312). Trudgill shifted the focus to contact-induced language change and brought in contact intensity as an alternative explanation for dialect diversification (see Schreier 2016 for a detailed discussion on such a strict dichotomy).

Kortmann and Szmrecsanyi (2011: 68-74) analyzed the sociolinguistic reality of vernacular universals from the viewpoint of dialect typology. They advocated the adoption of implicational, not absolute, principles and suggested focusing on nonstandard features with a wide areal and/or social reach, including pidgins and creoles, and to factor in genetic, areal, and historical relationships between different varieties. Distributional patterns of features in a World Englishes context thus should be classified in a more fine-grained system that includes typological categories such as (1) genuine universals, (2) typoversals (i.e. features that are common to languages of a specific typological type; e.g. postpositions in SOV languages), (3) phyloversals (i.e. features shared by a family of genetically related languages (e.g. languages belonging to the Indo-European language family that distinguish masculine and feminine gender), (4) areoversals (features common in languages that are in geographical proximity; e.g. finite complement clauses in languages in the Balkan sprachbund), (5) angloversals (i.e. features that tend to recur in vernacular varieties of a specific language), and (6) varioversals (features recurrent in language varieties with a similar sociohistory, historical depth, and mode of acquisition; e.g. resumptive pronouns in relative clauses found in English L2 varieties; Szmrecsanyi and Kortmann 2009; see Szmrecsanyi and Röthlisberger, Chapter 23, this volume).

As for a general taxonomy of dialect roots, the question is which of these categories should be most influential for the distribution of current patterns - or how the interplay of criteria combines to shape an ultimate outcome. In a cross-varietal study, Kortmann and Szmrecsanyi (2011: 276) found that the "varieties cluster very nicely according to whether they are L1 varieties ..., L2 varieties ..., or English-based pidgins and creoles ...and indeed better than geographically," concluding that "it is the variety type ... which is of towering importance" in the distribution of linguistic 
features among World Englishes (p. 274). Winford (2009: 208), in contrast, stressed that typological universals should not be offered as "explanatory principles.” Referring to Kiparsky (2008), he claimed that there was a need to "reconcile research that seeks to uncover typological generalizations, which are the result of recurrent processes of language change, with research directed at uncovering the universal principles underlying such processes" (Winford 2009: 209). In other words, principles of contactinduced language change (on a more micro-oriented level) accounted for distribution patterns among World Englishes, not the typological generalizations on a macro level per se. Similarly, Thomason (2009) discussed the interplay of contact-induced change and typological universals in historical language change. She rejected Trudgill's view of simplification as a result of contact-induced change and claimed that "linguistic changes involve both kinds of process - that is, various processes of contactinduced change and also universal tendencies of various kinds" (Thomason 2009: 349). In other words, the local-specific origin of features had to be taken into consideration along with universal criteria.

The second question, survival vs. loss of (English) dialect roots on the new-dialect contact scenario, draws on dialect typology, sociolinguistics, contact linguistics, dialectology, and English historical linguistics. Perhaps the major issue one needs to address is "why all of this has happened and whether there is an underlying scheme that has continued to drive and motivate the evolution of new varieties of English" (Kortmann and Schneider 2004: 1). The task here is to find out what features are selected where and why, why some are common, found all over the Englishspeaking world, whereas others are restricted to particular varieties, and so on. This is a complex issue: The diachrony of World Englishes, including diachronic corpora and data sources, are discussed by Huber (Chapter 21, this volume) and principles of dialect typology from a World Englishes perspective are sketched by Szmrecsanyi and Röthlisberger (Chapter 23, this volume), who introduce the electronic World Atlas of Varieties of English (eWAVE) in full detail. As this is referred to in much more detail in Chapter 23 in this volume, it suffices to say that the eWave can be used as a research tool for the study of World Englishes and learner Englishes generally. It distinguishes between Traditional L1 varieties (Orkney and Shetland English, Ozark English, etc.), High-Contact L1 varieties (Irish English, African American English, etc.), Indigenized L2 varieties (Chicano English, Pakistani English), English-Based Pidgins (Ghanaian Pidgin English, Tok Pisin) and English-based Creoles (Gullah, Krio, Hawai'i Creole) and there is (admittedly rather basic) variationist classification between features in terms of whether they are pervasive/obligatory, neither pervasive nor rare, extremely rare, or nonexistent.

The frequency ratings used in eWave allow us to affiliate British and overseas dialects, to establish links and offer sociohistorically informed explanations why some British dialect features are adopted and gain 
ground in World Englishes, whereas others do not. Based on historical evidence, we can reconstruct the history of dialect features and pinpoint their place of origin, which is instrumental in understanding their evolution via competitive interaction processes with other dialects and their features. Following Hickey and others, it is clear that roots do not remain static and are subject to change themselves, which means that there are high-contact scenarios that involve unprecedented interaction patterns of dialects from distinct regions and social classes (see Section 17.3).

\subsection{The Diagnosticity of Dialect Roots}

One of the most thorough attempts to reconstruct the legacy of dialect patterns is Montgomery's (1989) analysis of the formation of US Appalachian English, an isolated variety of American English that has a strong ancestral heritage of Irish, Northern Irish, and Scottish English. Based on sociohistorical data (see Schneider 2002) and data collected from ego documents such as emigrant letters (Auer, Schreier and Watts 2013), Montgomery asked rather holistically what evidence was necessary so that researchers could firmly establish a link between Appalachian English, Scottish, and Irish Englishes. He called for methodological, descriptive, historical, and analytical considerations as a detailed description of synchronic data needed to be entrenched in a historical corpus so as to assess present-day forms of English - Irish and Appalachian - and to reconstruct them at the time of emigration from the British Isles to Appalachia (see Britain, Chapter 7, this volume).

From a methodological point of view, the majority of migrations that gave rise to current World Englishes took place before the advent of permanent speech recordings. The oldest spoken data available are thus from speakers born around the mid-nineteenth century. This makes it challenging to localize sufficient quantities of data in order to not only have sporadic, often anecdotal reports of given features (as in logbooks or traveler diaries) but also have sufficient information on the context of grammatical features under study (Tagliamonte 2012; the Origins of New Zealand English (ONZE) corpus is a notable exception; Gordon et al. 2004). As data often come from written sources, there is always the possibility that grammatical forms are screened out or avoided, particularly when they are salient or sociolinguistically stigmatized (Schneider 2013). In other words, features may have been in existence but we might simply lack hard evidence of this fact.

From an analytical and interpretative perspective, we need to have as much information as possible on two points A and B of a temporal axis so as to retrace dialect evolution and feature inheritance. Two principal factors need to be considered: the overall proportions and relationships of the founding populations and their input varieties; and koineization 
and general contact effects between varieties before and during departure, on arrival, and in the inceptive phases of settlement (see Gordon et al. 2004 for a detailed discussion of these issues in the New Zealand context). Moreover, one also should account for other types of contact, such as between multilingual settlers and the native Amerindian ones in North America (Schneider 2007). We also need to filter in social information, namely how society was structured in both home and host environments and what sort of strata the early settlers came from: mobility and settlement patterns, social relationships, language attitudes, and so on. Retracing dialect roots is a complex task, depending on the availability of social, sociolinguistic, and historical data - which are often not sufficiently available. Sources typically offer information on certain aspects (e.g. language use, attitudes) but not necessarily all the background information required.

Nevertheless, it is possible to identify and pinpoint such features, sometimes even in minute detail, and I would suggest that they be placed along a localizability continuum, ranging from high to low. Obviously, the most important features in this context have high diagnostic value in that they are restricted to a small set of varieties. The exact positioning can be established by checking ratings and dialect maps on eWave, and a few selected features will serve to illustrate localizability in more detail.

\subsubsection{Root 1: The 'after' Perfect in Irish and Newfoundland English}

To start with a show-case scenario, the "after" perfect, as in

Brazil is after winning the World Cup ("Brazil has just won the World Cup")

provides a particularly clear example of how roots may be replanted successfully, without undergoing much change. The eWave lists merely two varieties where the feature is classified as pervasive or obligatory: Irish English and Newfoundland English (it is also attested in Sri Lankan English, which needs further substantiation; see the discussion in Kortmann and Szmrecsanyi 2004).

Historically, it has been suggested that Irish constructions such as

(2) Tha Iain air a bhith ag ithe an arain ("is Iain after COMP been at eating the bread")

were transferred via language contact when Irish English emerged, and here they survive and are stable in present-day varieties (Hickey 2013). The "after" construction, once it had taken hold in Ireland, was brought across the North Atlantic to Newfoundland from the seventeenth century onward. The Newfoundland population developed when the local cod fishery became a lucrative business; it involved major settlement groups from south-western England (Devon and Dorset) and the south-east 
counties of Ireland (Wexford and Waterford). Only small numbers of settlers arrived, and many of them arrived as part of a workforce with little intention to stay permanently. Most of the Irish settlers came in the eighteenth century, but there was a dramatic decline of immigration from the 1850s onward (see the social history provided by Clarke 2010: 72-75).

Given these contact patterns and sociohistorical relationships, the "morphosyntactic structure of vernacular NfldE [Newfoundland English] displays many conservative features inherited from its regional source varieties in southwest England and southeast Ireland" (Clarke 2004: 316), thus representing a quasi-laboratory setting to study long-term effects of dialect contact and interaction. Further evidence for the Irish English (IrE) roots of NfldE come from the area of lexis ... (sleveen "rascal," scrob "scratch").

\subsubsection{Root 2: Conjunction do in East Anglian and African American English}

Trudgill (2002) provided a reconstruction of conjunction do in East Anglian English (semantically equivalent to "otherwise”), as in

(3) Sing out, do we shall get drowned! ("Call out, or we shall be drowned")

and claimed that it underwent complex stages of phonological reduction, loss of lexical because if + pronoun, loss of tense marking of do and don't, grammatical extension to other environments, and, finally, loss of negative/positive polarity (Trudgill 2002: 13). Crucially in this context, conjunction do is

not found anywhere in the British Isles outside East Anglia. Nor, as far as I know, is it found anywhere else in the English-speaking world, with one exception - in the South-eastern United States.

(Trudgill 2002, 13)

Citations from the work of Zora Neal Hurston in the Dictionary of American Regional English (DARE) rendered several instances of conjunction do in literary African-American English usage:

(4) Dat's a thing dat's got to be handled just so, do it'll kill you ("that's a thing that has te handled just so, if you don't it will kill you”)

The explanation provided in DARE (that this was an abbreviation of if you do) accounted for some of the examples, but Trudgill (2002) argued that conjunction do in AAVE showed "progress towards the fully completed grammaticalisation also typical of East Anglia in that do is employed where don't might have been expected" (p. 13). In other words, AAVE would have collapsed polarity and neutralization in favor of do instead of don't. Trudgill quoted evidence from fieldwork notes and personal observations that the feature was currently found in spoken varieties (both African-American 
and Anglo-American) in coastal North Carolina. The possibility of independent developments was excluded; rather, do in East Anglia and AAVE was interpreted as a direct legacy, representing a feature with high diagnostic value for dialect roots:

this feature ... was brought to eastern North Carolina by settlers who were speakers of East Anglian dialects. In (at least some parts of) the southeastern United States, it was then not only retained in White nonstandard dialects of English but also acquired by speakers of AAVE ... It is undoubtedly true, however, that there is at least one nonstandard dialect feature with its origins in the British Isles ... which has been retained by some AAVE speakers.

(Trudgill 2002: 14-15).

As such, features like conjunction do may be important pieces of evidence for the sociolinguistic reconstruction of AAVE more generally (see Poplack and Tagliamonte 2001).

\subsubsection{Root 3: "Sequential" or "Irrealis" be done in African American and Liberian English}

Dialect roots are not restricted to the British Isles alone and it is certainly possible that features are transported from earlier established colonies to later offspring varieties, a process I would like to label "second-window transplantation." Once a colony with a distinctive variety is established, it may in turn come to serve as a focus for other settlements founded at a later stage, a process inherent in the discussion of emerging epicenters of English as world language (Hundt 2013). The Caribbean serves as a good case in point, as the earliest colonial possessions (e.g. St Kitts and Nevis [Baker and Bruyn 1998] or the Bermudas [Eberle 2017]) subsequently became donor varieties in their own right as settlers moved on to other locations. A good example of second-window exportation is the use of be done for resultatives or the future/conditional perfect (Rickford 1999: 6), as in

My ice cream be done melted by the time we get there

The combination of be and done as a preverbal tense/aspect marker indicates a resultative or a future conditional state, semantically similar to the standard-type English future perfect will have Ved-construction.

The origins of sequential be done are not well understood but it is reported with low frequency in Urban AAVE (eWave rating B) and Rural AAVE (eWave rating $\mathrm{C}$ ). Other than in the case of completive done, as in

(6) I done finish supper

there is no attestation of be done in historical British English, which strongly suggests that this is in fact a local African American English innovation. There are some claims (Labov 1998; discussed in Wolfram 2004) that the construction has recently taken on the function of 
a future resultative-conditional, referring to an inevitable consequence of a general condition or a specific activity, as in

(7) If you love your enemy, they be done eat you alive in this society

Dayton (1996) argued that this meaning, often pragmatically associated with direct speech acts (insults and warnings), is a semantic-aspectual development in twentieth-century AAVE (see discussion in Schneider 2008: 765; Wolfram 2004).

Crucially for the present purpose, only one other variety of World English also has be done: Liberian Settler English (eWave rating B), a variety transported to Liberia by African Americans in the early nineteenth century, so that it was "the Liberian cohort of African-American English” (Singler 2004: 231). There is a sociohistorical explanation: sequential be done was most likely brought to West Africa by speakers of early nineteenth-century AAVE, where it was adopted as a dialect root.

\subsubsection{Root 4: Remote yon/yonder}

Remote yon/yonder represents a more complex scenario than those presented so far. In the "after" perfect, conjunction do and remote sequential be done, there were few (British and American) varieties involved, which is evidence of first-(from the British Isles to the colonies) and second-window (from the first to offspring colonies) transplantation processes. Given the complexity of contact-induced change, there are cases where a simple oneon-one mapping is not accurate. The case of remote (or distal) yonder as a locative illustrates this well. It is found in

(8) Der a boat hoose yonder (Shetland and Orkney English; Melchers and Sundkvist 2013: 30)

(9) see that hill that be on the side - it all up top yonder (St Helenian English; Schreier 2008: 186)

An eWave search indicates that yonder is reported (with varying frequencies) in a total of sixteen varieties of English around the world: in the British Isles (the northern varieties, to be more specific), America (the Southeast and the Appalachians), the Caribbean, the South Atlantic, Africa, and also in the Pacific. It is found in Traditional L1 varieties, English-based Pidgins and Creoles and also in High-Contact L1 Varieties (see Table 17.1).

Yonder is globally spread and has taken hold firmly. As its British origins are more diverse (north of England, Isle of Man, Scotland, Shetland and Orkney Islands), it is less diagnostic and cannot with confidence be pinpointed to one particular area, making multiple inputs plausible (see Section 17.3). In American English, it is found in southeastern enclave varieties and in the Appalachians, the latter having been strongly 
Table 17.1 Donor source attribution for yonder (eWave ratings)

\begin{tabular}{lll}
\hline \hline A (feature pervasive or obligatory) & & \\
\hline $\begin{array}{l}\text { Variety } \\
\text { Orkney and Shetland English }\end{array}$ & Region & Type \\
Gullah & British Isles & Traditional L1 varieties \\
Barbadian Creole (Bajan) & Caribbean & English-Based Creoles \\
Eastern Maroon Creole & Caribbean & English-Based Creoles \\
Palmerston English & Pacific & English-Based Creoles \\
& & English-Based Creoles \\
\hline B (feature neither pervasive nor extremely rare) & \\
\hline North English dialects & British Isles & Traditional L1 varieties \\
Manx English & British Isles & Traditional L1 varieties \\
Scottish English & British Isles & Traditional L1 varieties \\
Appalachian English & America & Traditional L1 varieties \\
Southeast American enclave & America & Traditional L1 varieties \\
Guyanese Creole & Caribbean & English-Based Creoles \\
Vincentian English & Caribbean & English-Based Creoles \\
St Helenian English & South Atlantic & High-Contact L1 varieties \\
\hline C (feature exists but is extremely rare) & \\
\hline Rural African American English & America & High-Contact L1 varieties \\
Tristan da Cunha English & South Atlantic & High-Contact L1 varieties \\
Vernacular Liberian English & Africa & English-Based pidgins \\
\hline \hline
\end{tabular}

influenced by the Ulster Scots (thus suggesting a direct link, as we had in Liberia as well). Yonder also made its way into the Caribbean (from the British Isles presumably, though a secondary American input cannot be excluded), the South Atlantic, Africa (again via the settlers that influenced Liberian Settler English), and the Pacific (notably Palmerston English, Hendery 2015a, 2015b; see the following section). While it is still possible to retrace its diffusion, the patterning is much more widespread so that the overall diagnostic value of the feature is lower than in the cases previously discussed (particularly in what regards the Caribbean).

\subsubsection{Root 5: Negator ain't}

The last root discussed in detail here is ain't, which, though highly stigmatized, is "used world-wide as the negative form of both be and (auxiliary) have" (Anderwald 2012: 312) and also functions as a generic negator before main verbs. Ain't is a merged negator used for the auxiliaries be, have as well as didn't, as in Examples (9)-(14), all taken from Kortmann and Lunkenheimer (2013):

(9) I ain't really thinking about getting with J. or any other guy. (Chicano English; ain't = be)

(10) Them fellas ain't doing nothing. (Trinidadian Creole; ain’t = be) 
(11) I ain't got no money. (Australian English; ain't = have)

(12) Sister Ruth ain’t come yet o. (Liberian Settler English; ain't = have)

(13) They ain't tell me. (Liberian Settler English; ain’t = didn't)

(14) He ain't live too far. (Bahamian Creole; ain't = didn't)

Ain't as the negated form of be is attested in thirty-three varieties included in the eWave (ca. 40 percent): in all American and South Atlantic varieties, in nine out of twelve British varieties, as well as in most Australian and Caribbean dialects (see Figure 17.1). However, it features less often in Africa (where it is attested in Liberian Settler English, Vernacular Liberian English, and White Zimbabwean English) and the Pacific (Norfolk Islands/Pitcairn English) and is completely absent in South and Southeast Asia. There is thus a clear areal concentration in America and the South Atlantic, followed by the British Isles and to a lesser extent Australia and the Caribbean (Bahamian Creole, Barbadian Creole, and Vincentian Creole). Ain't mostly occurs in L1 varieties and high-contact L1 varieties have a slightly higher attestation than traditional L1 varieties. This is to be expected as the regions with the highest attestation rates (America, South Atlantic, and the British Isles) include a majority of L1 varieties. The low percentages for indigenized L2 varieties and Englishbased Pidgins can be explained by the fact that most L2 varieties and Pidgins occur in the regions that have the lowest attestation, namely

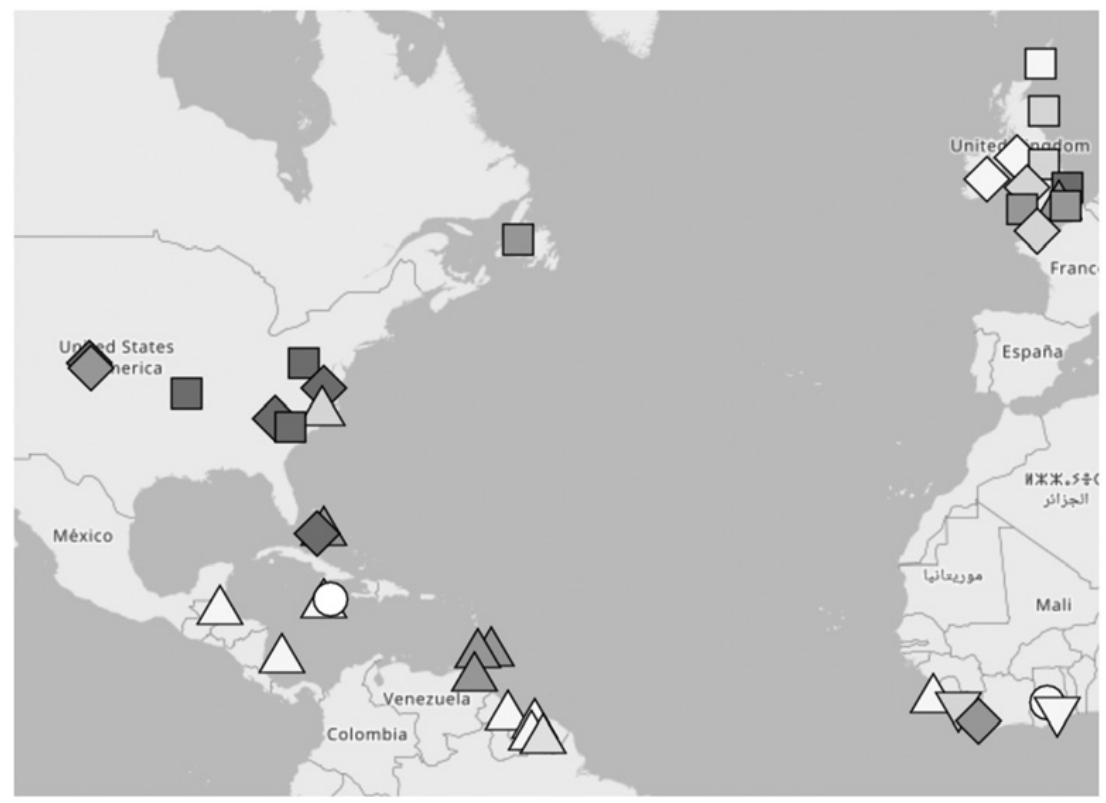

Figure 17.1 ain't for negated be in eWAVE 


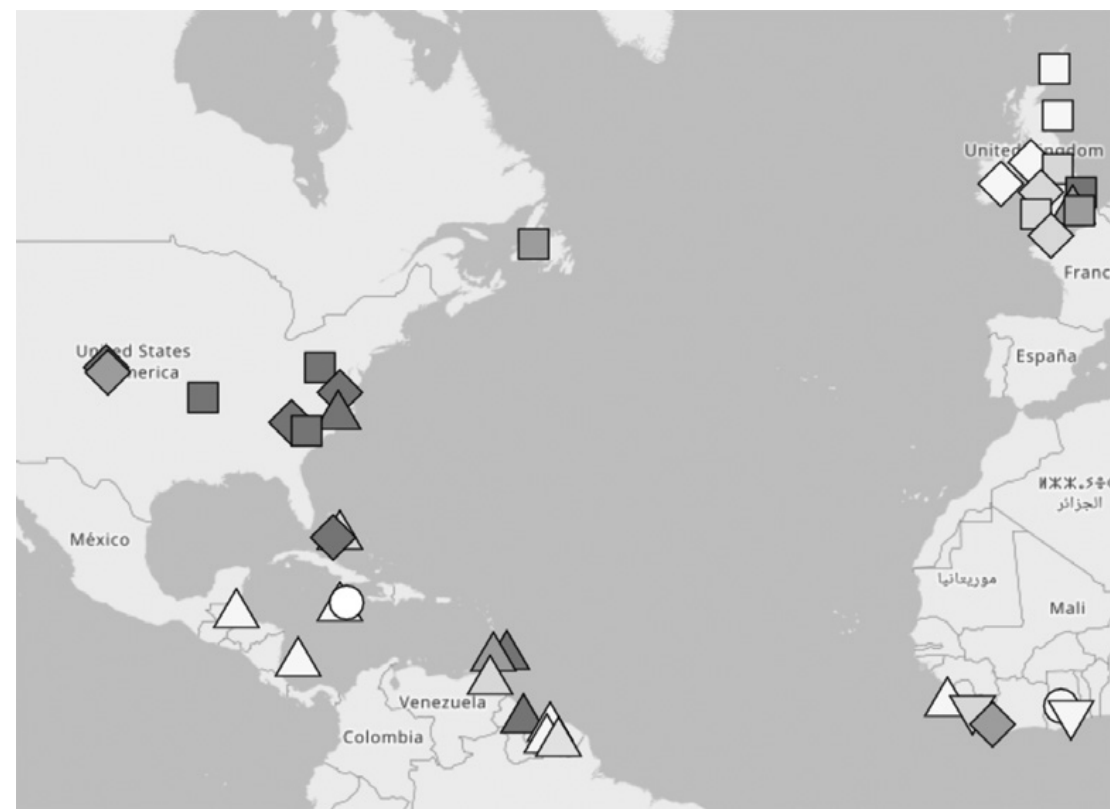

Figure 17.2 ain't for negated have in eWAVE

Africa, Asia, and the Pacific. Thus, variety type distribution very much correlates with regional distribution.

The overall attestation of ain't as the negated form of have in eWAVE is ca. 40 percent (see Figure 17.2), thus slightly lower than for negated be, yet the attestations in the individual world regions are quite similar. It is more common in America and in the Caribbean than in the British Isles and Australia, rare in the Pacific, and inexistent in Asia. With regard to variety types, the feature is frequent in high-contact L1 and traditional L1 varieties.

Ain't as a common negator, finally, is least frequent, reported in only ca. 21 percent of all varieties, and one of the most infrequent negation features in World Englishes generally (Anderwald 2012: 312). It is most common in America, particularly in AAVE:

(15) I hop' ya ain't wanna kno' much mo' 'cause I 'bout through. (Earlier African American Vernacular English) (Kortmann and Lunkenheimer 2013)

and in the Caribbean (Bahamian English, Bajan, Guyanese Creole) but has attested absence in the British varieties and Africa (with the exception of the two Liberian varieties). Figure 17.3 shows that it is entirely absent in Asia, Australia, the Pacific, and the South Atlantic.

In other words, general negator use is restricted to the American and Caribbean varieties but absent in the British donor varieties, even though ain't is historically attested for both have and be (the one exception is 


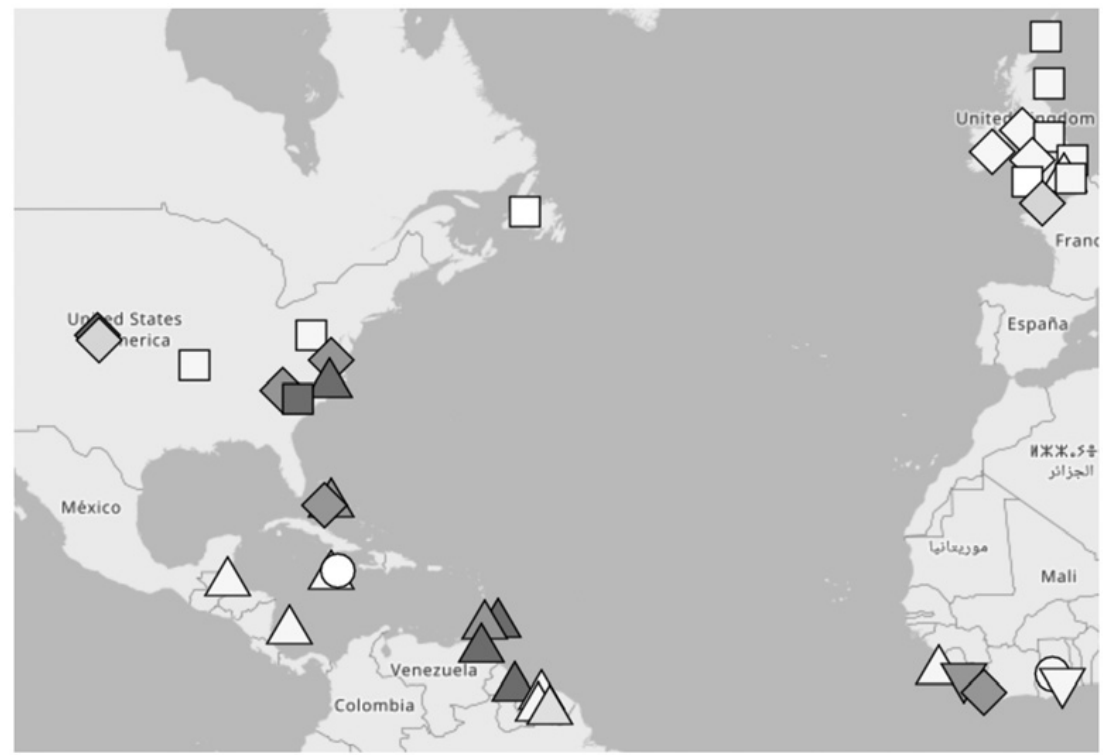

Figure 17.3 ain't as generic negator in eWAVE

Channel Island English, where it is reported to be rare: "in the JersE [Jersey English] data, there is just a single occurrence of ain't in the interview with a 48-year old male speaker"; Rosen 2014: 167).

The distribution of this particular dialect root in World Englishes can be summarized as follows: ain't for be and have is mostly found in the British Isles (with a predominance in the south), in the Caribbean, and in nearly all American varieties. It is also found in Africa, though only in the Liberian Settler English and Vernacular Liberian English. Ain't for be is the most widespread usage, with attestations in the South Atlantic and in the Pacific also (Palmerston Island English). The overall hierarchy with regard to widespread distribution is:

ain't for be

$$
\begin{aligned}
& >\text { ain't for have } \\
& \quad>\text { ain't as general negator }
\end{aligned}
$$

This hierarchy finds support in the overall number of varieties (thirtythree, thirty-two, sixteen) and - as a corollary - also in regional spread and variety type. This suggests that a dialect root (ain't) was transplanted out of the British Isles (or, to be more specific, the southern varieties) into the transatlantic colonies. Both usages (be and have) were common at the time of colonization. The general usage as a negator, however, represents an independent local phenomenon, restricted to America and the Caribbean and not found in the donor sources. Following Anderwald (2012: 312): 
It is unclear which world region influenced which, but it is not completely implausible to speculate that in the evolution of creoles in the Caribbean, the negator that was frequently employed by the slave holders to negate the frequent verbs have and be was overextended by the slaves themselves to a more general use.

From the Creoles, the feature might have "spread to Gullah and African American English, and may later have extended to Chicano English" (Anderwald 2012: 312) and other American varieties. Anderwald goes on to claim that "[t]he distribution across variety types only mirrors the distribution inside these geographical areas" (p. 312). Importantly, most high-contact L1 varieties are American and almost all of the Creoles are in the Caribbean. Thus, one could make a case that areal and sociohistorical factors might have a stronger influence on the feature's distribution than variety type. There was also second-window transplantation of all three usages back across the Atlantic into Liberia (where they were adopted by Liberian Vernacular English via the Liberian Settler Varieties). Ain't thus took a life of its own, so to speak; it originated as a negator for have and be in the British Isles and later took on an additional function. Roots may develop further semantic/pragmatic usages or change to adopt more general usages induced by extensive language and dialect contact (perhaps via ongoing grammaticalization).

To sum up, the discussion of five selected features, the "after" perfect, conjunction do, sequential be done, remote yon/yonder, and negator ain't, has shown how dialect features may differ in terms of donor source attribution, regional spread, and potential for additional developments. The first three features were characterized by a high degree of localizability; they were assigned to one region of origin and one place in the newly established overseas colonies (America and the Caribbean). The "after" perfect is a direct legacy of Southern Irish English, brought to Newfoundland by fishermen in the eighteenth century; conjunction do, though the historical connections are somewhat sketchy, could have been brought to coastal North Carolina by East Anglian settlers (Trudgill argued against the possibility of independent innovation). Similarly, be done had both a donor and a recipient variety but the process represented indirect legacy, or rather, second-window transplantation, as it was a colonial (Caribbean or American) innovation brought to Liberia by slaves, speaking forms of nineteenth-century African American English. Both first- and secondwindow transplantation provide showcase scenarios that allowed us to investigate dialect change and outcomes of contact types in new linguisticecological environments (see Poplack and Tagliamonte 2001 on the development of African American English in diasporic settings; see Zipp, Chapter 6, this volume).

However, as the discussion of remote yon/yonder and ain't has shown, one-on-one mapping of dialect features from donor to recipient variety is 
not usually straightforward. There are several reasons. First (and perhaps most importantly), the same feature may be present in several input varieties: yon/yonder is reported throughout the English North, Scotland, the Orkneys, and Shetlands, as well as on the Isle of Man, so pinpointing one particular donor source is not possible in these cases. Generally speaking, Trudgill (1986) already claimed that settlement by speakers of one donor variety is the exception rather than the norm. As the analysis of varieties such as Tristan da Cunha English (Schreier 2002) has shown, selection chances are likely to be higher when features are present in dialects spoken by several founding populations. Second, the interaction of dialects may give rise to additional developments. One good example here is linguistic camouflaging, when "a vernacular form resembles a standard or different vernacular form so closely that it is simply assumed to be identical to its apparent structural counterpart” (Wolfram 2004: 114). Wolfram (1994) suggested that, in an example such as "They call themselves dancing," camouflaging may involve syntactic expansion and a subsequent semantic-pragmatic reorientation. While counterfactual call oneself is common with noun phrases (e.g. "They call themselves experts") or adjective phrases (e.g. "They call themselves cheap"), its structural expansion to include Verb+ing complements sets African American English apart from most other American English dialects (see also Spears 1982), who argued that the semi-auxiliary come has acquired a specific semantic-pragmatic role of indicating speaker indignation).

Though this is personal speculation, camouflaging processes may arguably increase and intensify due to second-window transplantation. Accordingly, quantitative analyses to uncover language-internal constraints should ideally accompany feature-based analyses that are qualitative in nature.

\begin{tabular}{lcr|} 
High & \\
irrealis be done & remote yon(der) & multiple negation \\
'after' perfect & verbal $-s$ & past be leveling \\
conjunction do & infinitival for to \\
amn't in tag Qs & relativizer what & me in coord. subj. \\
relativizer as & subjective us & double comparatives \\
&
\end{tabular}

Figure 17.4 Diagnosticity and localizability of dialect roots 
Figure 17.4 summarizes the diagnostic value of dialect features and suggests a continuum, ranging from high to low degrees of localization. Features toward the left end are ideal for an analysis of founder effects (Mufwene 2001), as they can be clearly demarcated regionally, both in donor and in recipient varieties. Toward the right end there are general features, characterized by wide regional diffusion, both in donor and in recipient dialects. In their extreme form, they are what Chambers (2009: 258) has classified as "vernacular roots" (multiple negation, past be leveling, etc.; see Section 17.2).

The dialect roots of World Englishes thus differ in their distribution and regional affiliation, and this leads to the second question that needs to be considered here: why some features thrive whereas others do not.

\subsection{The Growth of Roots}

Recent debates on the principal motivation of feature selection have primarily focused on the roles of (1) input strength and (2) identity. Whereas Trudgill (2004) has categorically denied any influence of identity, Hickey (2004) and Schneider (2007) have included an indexical function of dialect features in their models. The question is too complex to go into much detail here (see Schreier 2013 for a more thorough critique), so it is sufficient to state that attempts to explain feature selection should consider the following factors: the concentration and frequency of features in the input varieties, the social relationships and settlement patterns of the migrant populations, the social meaning of features (particularly when it comes to overt sociolinguistic stigmatization), and the intensity of connections (including human traffic) with the homeland (e.g. via transnational ties; Bolander, Chapter 29, this volume).

As for input strength, features with wider distribution patterns and frequent usage across speech communities have an overall advantage, so the concentration of dialects throughout the wider sociolinguistic ecology of founder communities is an important criterion to consider (see Section 17.1). A good example comes from New Zealand English, where Schreier et al. (2003) showed that new-dialect formation processes were a direct reflection of local feature proportions in transplanted dialects. They analyzed the maintenance of voiceless labiovelar / $\mathrm{hw}-/$ fricatives (minimal pairs Wales $\sim$ whales, witch $\sim$ which) in three selected regions (Otago/Southland, Canterbury, and the North Island) and found that there was considerable regional variation in early twentieth-century New Zealand English. Whereas New Zealanders from the North Island and Canterbury were predominantly using $/ \mathrm{w} /$ (here the $/ \mathrm{hw} / \sim / \mathrm{w} /$ merger was practically completed by 1950), speakers from the Southland and 
Table 17.2 /hw- w-/ variation in early twentieth-century New Zealand English (from Schreier et al. 2003: 258)

\begin{tabular}{llll}
\hline \hline & /hw/ & /w/ & percent /hw/ \\
\hline Southland & 441 & 666 & $40.0 \%(441 / 1107)$ \\
Canterbury & 51 & 596 & $7.9 \%(51 / 647)$ \\
North & 21 & 369 & $5.4 \%(21 / 390)$ \\
\hline \hline
\end{tabular}

Otago regions had high levels of /hw-/ well into the second half of the twentieth century (Table 17.2).

The regional distribution of the variable was linked to population demographics and ancestral effects, thus correlating with the input strength of / hw-/ retaining donor dialects. /hw-/ survival in the Otago/Southland dialect region was explained by high input frequency and the disproportionally high input of Scottish and Irish settlers, where a /hw-/ and /w-/ distinction survives until today. In the other regions, the social configuration and the local contact and mixture situations were substantially different, so /hw-/ was not adopted. Here the inputs mainly came from the south of England, where /hw-/ was a minority feature, and this enhanced leveling-out in the local forms of NZE. A high overall presence of / hw-/ variants in the inputs had an enhancing effect on adoption and maintenance, an effect that was arguably even stronger given that the feature was regionally marked (see Hickey 2003a, 2004). These effects may have correlated with settler numbers and may in fact be more persistent in small communities, where founder populations have a particularly high impact. On Palmerston Island, for instance, Henry Marsters, who came from the Midlands or the English North and established the community in the 1850s, left dialect roots such as a STRUT vowel that has FоOт, or unetymological /h/ before vowels with initial-stress vowels (helse, hunderstand), a conservative British dialect feature that also has taken root elsewhere (e.g. on Tristan da Cunha; Schreier 2019).

Similarly, Hickey (2003a) argued that the numerical proportions between colonizers and their degree of social organization are important factors in the new-dialect formation process. Based on a chronology of Irish settlements in New Zealand, Hickey suggested that the earliest settlement forms were socially stratified and that the donor dialects' prestige was a decisive factor for the adoption of dialect features. Accordingly, this might possibly explain why Irish English, though present early and sociodemographically prominent in large settlements such as Auckland, disappeared without having much of an impact, simply because the social stigma of the speakers and their dialects was too strong. According to Hickey, supraregionalization ("an historical process whereby varieties of a language lose specifically local features and becomes less regionally bound”; Hickey 2003b: 351) is a key factor in feature adoption and selection: "[D]ialect speakers progressively 
adopt more and more features of a non-regional variety which they are in contact with. There does not have to be direct speaker contact" (2003a: 236), so that the new variety can "be seen as a product of unconscious choices made across a broad front in a new society to create a distinct linguistic identity" (Hickey 2003a: 215). A supraregional form, according to Hickey, would emerge in the melting pot settlements first, where there were mixed populations of high density and size, and then spread to rural settlements that subsequently would become dialectally distinctive. On the other hand, sustained contacts with the "mother country" are also crucial. Close links, bidirectional migration patterns and high levels of human traffic enable interaction between donor and recipient dialects. As a result, innovations may be passed on and picked up; a good example here is non-rhoticity, which was "transplanted" to coastal American settings (Boston, Savannah) but did not take root further inland where there was little contact with British colonists.

The issue of identity has become central in recent approaches to the emergence of World Englishes. For instance, it is central in Schneider's (2007) model of the evolution of postcolonial Englishes (e.g. in the maintenance of transnational ties), and

represents an individual stance with respect to the social structures of one's environment, an attitude that also contributes to group formation and group delimitation through establishing an "us vs. them" construct of human alignments and through establishing relationships of similarity or difference - that is, social classification and individual affiliation.

(Schneider 2007: 264)

In sum, feature adoption, or the survival of dialect roots, is a complex process that depends on the sociolinguistic nature of a contact setting, its social structuring and amount of stratification, the amount of dialects in dialect contact situations, and of course also on indexical values such as stigma and prestige. These have to be assessed independently in each setting.

\subsection{Conclusion}

This chapter has looked into selected aspects of dialect roots in World Englishes. Complementing other chapters in this volume, particularly the methodological demands of diachronic reconstruction (Huber, Chapter 21), earlier accounts of British English during colonization (Britain, Chapter 7), and the impact of contact-induced language and dialect change (Britain, Chapter 7; Mufwene, Chapter 5; Hickey, Chapter 2; Zipp, Chapter 6), the focus here has been on individual dialect roots: their adoption, selection, and subsequent development in newly forming colonial environments.

There are various reasons why dialect roots, that is, dialectal features that are permanently adopted in emerging World Englishes (ranging from 
traditional L1 varieties to pidgins and creoles), thrive and develop under dialect transportation and contact conditions. The originally British varieties that represent a substantial input in colonial settings are in a process of competition, as a result of which some features survive whereas others disappear. Criteria such as concentration and frequency of features, their regional distribution, and sociolinguistic significance all have to be taken into account in such an analysis. There is evidence that roots with wider usage have higher selection chances in the formation of World Englishes (even though frequency alone is not deterministic, in the sense of Trudgill [2004], for the ultimate outcome).

More often than not, it is difficult to map the dialectal origins of features. Though one-on-one mapping exists, as in the "after" perfect or conjunction do, ideally enabling a case study of dialect transplantation and also of change under potential dialect contact conditions (with potential morphosyntactic or semantic/pragmatic effects), the picture is usually less clear, particularly when roots are brought to the colonies via several donor varieties (e.g. multiple negation). As a result, features that have high attestation levels in the eWave (Me instead of $I$ in coordinate subjects) are less important for research on dialect roots (though of course they are valuable for dialect typology and the regional distribution of angloversal features).

Roots should be classified with regard to their degree of localizability, ranging from high to low, which emerged as an important criterion for research on contact-induced language change. Moreover, first- vs. secondwindow transportation may offer insights into typological affiliations of World Englishes and also help explain changes that originate as local innovations (e.g. done been). Offspring varieties can develop and spread their roots as well (exemplified by the connection between African American English and the Liberian varieties). As for survival rate, roots may persist and survive for generations (/hw-/ in New Zealand, verbal -s agreement in Appalachia) before they gradually disappear (conjunction do has all but disappeared in coastal North Carolina). To sum up, dialect roots provide an ideal background for research on the diversification of World Englishes. They allow a better understanding of the origins and development of these features, of variation and change processes, and help pinpoint potential donor sources from a historical perspective. They have been integrated into the research canon in diverse fields, from pidgin and creole studies, dialect typology, language variation and change to regional dialectology and contact linguistics.

\section{References}

Anderwald, Lieselotte. 2012. Negation in varieties of English. In Raymond Hickey, ed. Areal Features of the Anglophone World. Berlin: de Gruyter, 299-328. 
Auer, Anita, Daniel Schreier and Richard J. Watts, eds. 2015. Letter Writing and Language Change. Cambridge: Cambridge University Press.

Baker, Philip and Adrienne Bruyn, eds. 1998. St. Kitts and the Atlantic Creoles: The Texts of Samuel Augustus Mathews in Perspective. London: Battlebridge Publications.

Blommaert, Jan. 2010. The Sociolinguistics of Globalization. Cambridge: Cambridge University Press.

Chambers, J. K. 2004. Dynamic typology and vernacular universals. In Bernd Kortmann, ed. Dialectology Meets Typology. Berlin: Mouton de Gruyter, 127-145.

Chambers, J. K. 2009. Sociolinguistic Theory: Linguistic Variation and Its Social Significance (3rd ed.). Oxford: Blackwell.

Clarke, Sandra. 2004. Newfoundland English: Phonology. In Edgar W. Schneider, Kate Burridge, Bernd Kortmann, Rajend Mesthrie and Clive Upton, eds. A Handbook of Varieties of English, Vol. 1. Berlin: de Gruyter, 366-382.

Clarke, Sandra. 2010. Newfoundland and Labrador English. In Daniel Schreier, Peter Trudgill, Edgar W. Schneider and Jeffrey P. Williams, eds. The LesserKnown Varieties of English. An Introduction. Cambridge: Cambridge University Press, 72-91.

Crystal, David. 2003. English as a Global Language (2nd ed.). Cambridge: Cambridge University Press.

Dayton, Elizabeth. 1996. Grammatical categories of the verb in AfricanAmerican Vernacular English. Unpublished doctoral dissertation, University of Pennsylvania.

Eberle, Nicole. 2017. “They're trying to hear English, which they are hearing, but it's Bermudian English": Bermudian English - Origins and Variation. Unpublished doctoral dissertation, University of Zurich.

Filppula, Markku, Juhani Klemola and Heli Paulasto, eds. 2009. Vernacular Universals and Language Contacts: Evidence from Varieties of English and Beyond. New York: Routledge.

Gordon, Elisabeth, Lyle Campbell, Jennifer Hay, Margaret Maclagan, Andrea Sudbury and Peter Trudgill. 2004. New Zealand English: Its Origins and Evolution. Cambridge: Cambridge University Press.

Hendery, Rachel. 2015a. Palmerston Island English. In Jeffrey P. Williams, Edgar W. Schneider, Peter Trudgill and Daniel Schreier, eds. The LesserKnown Varieties of English: Further Case Studies. Cambridge: Cambridge University Press, 267-287.

Hendery, Rachel. 2015b. One Man Is an Island: The Speech Community William Marsters Begat on Palmerston Island. London: Battlebridge Publications.

Hickey, Raymond, ed. 2003a. Motives for Language Change. Cambridge: Cambridge University Press.

Hickey, Raymond. 2003b. How and why supraregional varieties arise. In Marina Dossena and Charles Jones, eds. Insights into Late Modern English. Frankfurt: Peter Lang, 351-373. 
Hickey, Raymond, ed. 2004. Legacies of Colonial English: Studies in Transported Dialects. Cambridge: Cambridge University Press.

Hickey, Raymond. 2013 English as a contact language in Ireland and Scotland. In Daniel Schreier and Marianne Hundt, eds. English as a Contact Language. Cambridge: Cambridge University Press, 88-105.

Hundt, Marianne. 2013. The diversification of English: Old, new and emerging epicentres. In Daniel Schreier and Marianne Hundt, eds. English as a Contact Language. Cambridge: Cambridge University Press, 182-203.

Kachru, Braj B., Yamuna Kachru and Cecil Nelson. 2006. The Handbook of World Englishes. Oxford: Wiley.

Kiparsky, Paul. 2008. Universals constrain change; change results in typological generalizations. In Jeff Good, ed. Language Universals and Language Change. Oxford: Oxford University Press, 333-356.

Kortmann, Bernd and Kerstin Lunkenheimer, eds. 2013. The Electronic World Atlas of Varieties of English. Leipzig: Max Planck Institute for Evolutionary Anthropology. http://ewave-atlas.org

Kortmann, Bernd and Edgar W. Schneider. 2004. General introduction. In Bernd Kortmann and Edgar W. Schneider, eds. A Handbook of Varieties of English: A Multimedia Reference Tool. Berlin: de Gruyter, 1-9.

Kortmann, Bernd and Benedikt Szmrecsanyi. 2004. Global synopsis: Morphological and syntactic variation in English. In Edgar W. Schneider, Kate Burridge, Bernd Kortmann, Rajend Mesthrie and Clive Upton, eds. A Handbook of Varieties of English, Vol. 2: Morphology and Syntax. Berlin: Mouton de Gruyter, 1142-1202.

Kortmann, Bernd and Benedikt Szmrecsanyi. 2011. Parameters of morphosyntactic variation in World Englishes: Prospects and limitations of searching for universals. In Peter Siemund, ed. Linguistic Universals and Language Variation. Berlin: de Gruyter, 264-290.

Labov, William. 1998. Co-existent systems in African-American Vernacular English. In Salikoko Mufwene, John R. Rickford, Guy Bailey and John Baugh, eds. The Structure of African-American English: Structure, History and Use. London and New York: Routledge, 110-153.

Lim, Lisa and Umberto Ansaldo. 2015. Languages in Contact. Cambridge: Cambridge University Press.

Melchers, Gunnel and Peter Sundkvist. 2013. Orkney and Shetland. In Daniel Schreier, Peter Trudgill, Edgar W. Schneider and Jeffrey P. Williams, eds. The Lesser-Known Varieties of English. An Introduction. Cambridge: Cambridge University Press, 17-34.

Mesthrie, Rajend and Rakesh Bhatt. 2008. World Englishes: The Study of New Linguistic Varieties. Cambridge: Cambridge University Press.

Montgomery, Michael. 1989. Exploring the roots of Appalachian English. English World-Wide 10: 227-278.

Mufwene, Salikoko. 2001. The Ecology of Language Evolution. Cambridge: Cambridge University Press. 
Poplack, Shana and Sali Tagliamonte. 2001. African American English in the Diaspora. Oxford: Blackwell.

Rickford, John E. 1999. Phonological and grammatical features of African American Vernacular English. In John R. Rickford, ed. African American English. Malden, MA: Blackwell, 3-14.

Rosen, Anna. 2014. Grammatical Variation and Change in Jersey English. Amsterdam: Benjamins.

Schneider, Edgar W. 2002. Investigating variation and change in written documents. In Jack K. Chambers, Peter Trudgill and Natalie SchillingEstes, eds. The Handbook of Language Variation and Change. Oxford: Blackwell, 67-96.

Schneider, Edgar W. 2007. Postcolonial English: Varieties Around the World, Cambridge: Cambridge University Press.

Schneider, Edgar W. 2008. Synopsis: Morphological and syntactic variation in the Americas and the Caribbean. In Edgar W. Schneider, ed. Varieties of English, Vol. 2: The Americas and the Caribbean. Berlin: de Gruyter, 763-776.

Schneider, Edgar W. 2011. English Around the World: An Introduction. Cambridge: Cambridge University Press.

Schneider, Edgar W. 2013. Investigating historical variation and change in written documents: New perspectives. In Jack K. Chambers and Natalie Schilling, eds. The Handbook of Language Variation and Change (2nd ed.). Oxford: Blackwell, 57-81.

Schreier, Daniel. 2002. Terra incognita in the Anglophone world: Tristan da Cunha, South Atlantic Ocean. English World-Wide 23: 1-29.

Schreier, Daniel. 2008. St Helenian English: Origins, Evolution and Variation. Amsterdam: John Benjamins.

Schreier, Daniel. 2009. Language in isolation, and its implications for variation and change. In Blackwell Language and Linguistics Compass 3. Oxford: Blackwell Publisher.

Schreier, Daniel. 2013. English as a contact language: Lesser-known varieties. In Daniel Schreier and Marianne Hundt, eds. English as a Contact Language. Cambridge: Cambridge University Press, 149-164.

Schreier, Daniel. 2016. Contact histories and simplification: Some typological and sociolinguistic considerations. In Guido Seiler and Raffaela Bächler, eds. Complexity, Isolation and Variation. Berlin: Mouton de Gruyter, 139-157.

Schreier, Daniel. 2019. /h/ insertion as a “camouflaged archaism”? Dialect contact, colonial lag and the feature pool in South Atlantic English. Diachronica 36(1): 36-64.

Schreier, Daniel, Peter Trudgill, Edgar W. Schneider and Jeffrey P. Williams, eds. 2010. The Lesser-Known Varieties of English. An Introduction. Cambridge: Cambridge University Press.

Schreier, Daniel, Elizabeth Gordon, Jennifer Hay and Margaret Maclagan. 2003. The regional and sociolinguistic dimension of / hw-/ maintenance 
and loss in early 20th-century New Zealand English. English World-Wide 24: 245-69.

Singler, John V. 2004. The morphology and syntax of Liberian settler English. In Bernd Kortmann and Edgar W. Schneider, eds. A Handbook of Varieties of English: A Multimedia Reference Tool. Berlin: de Gruyter, PAGES.

Spears, Arthur K. 1982. The Black English semi-auxiliary come. Language 58(4): 850-872.

Szmrecsanyi, Benedikt and Bernd Kortmann. 2009. Vernacular universals and angloversals in a typological perspective. In Markku Filppula, Juhani Klemola and Heli Paulasto, eds. Vernacular Universals and Language Contacts: Evidence from Varieties of English and Beyond. London: Routledge, 33-53.

Tagliamonte, Sali A. 2012. Roots of English: Exploring the history of dialects. Cambridge: Cambridge University Press.

Thomason, Sarah G. 2009. Why universals versus contact-induced change? In Markku Filppula, Juhani Klemola and Heli Paulasto, eds. Vernacular Universals and Language Contacts: Evidence from Varieties of English and Beyond. London: Routledge, 349-64.

Trudgill, Peter. 1986. Dialects in Contact. Oxford: Blackwell.

Trudgill, Peter. 2002. Sociolinguistic Variation and Change. Edinburgh: Edinburgh University Press.

Trudgill, Peter. 2004. New Dialect Formation: The Inevitability of Colonial Englishes. Edinburgh: Edinburgh University Press.

Trudgill, Peter. 2009. Vernacular universals and the sociolinguistic typology of English dialects. In Markku Filppula, Juhani Klemola and Heli Paulasto, eds. Vernacular Universals and Language Contacts: Evidence from Varieties of English and Beyond. London: Routledge, 302-320.

Watts, Richard J. and Peter Trudgill. 2002. Alternative Histories of English. London and New York: Routledge.

Williams, Jeffrey P., Edgar W. Schneider, Peter Trudgill and Daniel Schreier, eds. 2015. The Lesser-Known Varieties of English: Further Case Studies. Cambridge: Cambridge University Press.

Winford, Donald. 2009. The interplay of 'universals' and contact-induced change in the emergence of World Englishes. In Markku Filppula, Juhani Klemola and Heli Paulasto, eds. Vernacular Universals and Language Contacts: Evidence from Varieties of English and Beyond. London: Routledge, 206-30.

Wolfram, Walt. 1994. On the sociolinguistic significance of obscure dialect structures: NPi call NPi V-ing in African American Vernacular English. American Speech 69: 339-360.

Wolfram, Walt. 2004. The grammar of urban African American Vernacular English. In Bernd Kortmann and Edgar W. Schneider, eds. A Handbook of Varieties of English: A Multimedia Reference Tool. Berlin: de Gruyter, 111-32. 